\title{
Early Expression of High-Affinity Receptor for Immunoglobulin E (FceRI) during Differentiation of Mouse Mast Cells and Human Basophils
}

\author{
Helen L. Thompson, “ Dean D. Metcalfe, ${ }^{*}$ and Jean-Pierre Kinet ${ }^{*}$ \\ ${ }^{*}$ Mast Cell Physiology Section, Laboratory of Clinical Investigation, National Institute of Allergy and Infectious Diseases, \\ and ${ }^{\ddagger}$ Chemical Immunology Section, Arthritis and Rheumatism Branch, National Institute of Arthritis \\ and Musculoskeletal Diseases, National Institutes of Health, Bethesda, Maryland 20892
}

\begin{abstract}
Immediate hypersensitivity is due to the release of mediators from mast cells and basophils after the crosslinking of FceRI. The appearance of such receptors was examined during differentiation of human and mouse bone marrow cells cultured in the presence of IL-3. As already reported, mouse bone marrow yield cultures of $>95 \%$ mast cells by 3 wk, whereas human bone marrow develop into cultures comprising $25 \%$ basophils by 3 wk.

Here we show that transcripts for FceRI subunits and membrane-associated receptors are apparent by 1 wk in both human and murine IL-3-dependent bone marrow cells. These cells contain few, if any, granules. The expression of transcripts and the number of receptor-positive cells continue to increase over 3 wk of culture. In parallel, a progressively larger number of cells become increasingly granulated to finally resemble either basophils or mast cells. Mature peripheral human basophils also contain transcripts for FceRI and, therefore, may have the potential to synthesize de novo receptors.

The early appearance of FceRI during cell differentiation may be important for these cells to respond to IgE-mediated stimuli before granulation. The physiologic role of $F c \in R I$ could be to mediate lymphokine production (IL-3, IL-4, IL-6, and granulocyte/macrophage colony-stimulating factor) without inducing cellular degranulation. (J. Clin. Invest. 1990. 85:1227-1233.) mast cells • basophils • immunoglobulin E receptor
\end{abstract}

\section{Introduction}

The high-affinity receptor for IgE is found exclusively on the surface of mast cells and basophils (1). The binding of IgE to its receptor does not produce any apparent signal. Binding of multivalent antigens, however, to receptor-bound IgE aggregates the complexes on the cell surface, and the consequent aggregation of receptors induces degranulation of the cell and the release and generation of mediators of the allergic reaction (1).

The high-affinity receptor for IgE (FceRI) is a complex of noncovalently attached subunits. It is a tetramere of one IgEbinding $\alpha$ chain $(2,3)$, one $\beta$ chain $(4,5)$, and two identical

Address reprint requests to Dr. H. Thompson, Room 11C208, Building 10, Mast Cell Physiology Section, National Institute of Allergy and Infectious Diseases, National Institutes of Health, 9000 Rockville Pike, Bethesda, MD 20892.

Received for publication 18 August 1989 and in revised form 17 November 1989

The Journal of Clinical Investigation, Inc.

Volume 85, April 1990, 1227-1233 disulfide-linked $\gamma$ chains $(6,7)$. Complementary DNA clones for the rat $\alpha(8,9), \beta(10)$, and $\gamma(11)$ and for the human $\alpha(9$, $12)$ have been isolated. We have found recently that the requirements of the human and rodent receptor to reach the cell surface are different, at least in transfected cells $(11,13)$. Cotransfection of the $\alpha, \beta$, and $\gamma$ genes is necessary to induce sufficient expression of the rodent receptor (11), while transfection of the $\alpha$ and $\gamma$ genes seems sufficient for efficient expression of the human receptor (13).

Nothing is known, however, about the relationship between FceRI expression and basophil and mast cell differentiation. For this reason, we have analyzed the temporal expression of FceRI in both human and mouse IL-3-dependent bone marrow cultures. It is known that when bone marrow cells are cultured in vitro in the absence of exogenous growth factors, the cells fail to differentiate and lose viability; however, in the presence of IL-3, proliferation proceeds rapidly and a substantial number of cells undergo morphological changes to adopt the phenotypic characteristics of mast cells in murine or basophils in human bone marrow cultures (14-18). In this paper, we report that transcripts for the subunits of the IgE receptor and subsequently surface expression of Fc $\in R I$ appear at an early stage of differentiation in cultures destined to develop significant numbers of mouse mast cells or human basophils.

\section{Methods}

Materials. The following were purchased: RPMI 1640, Hepes (Biofluids, Inc., Rockville, MD), penicillin/streptomycin, nonessential amino acids, L-glutamine, sodium pyruvate (Flow Laboratories, Inc., McLean, VA), and FCS (HyClone Laboratories, Logan, UT).

Mouse bone marrow cultures. 6-10-wk-old BALB/c mice were killed by $\mathrm{CO}_{2}$ asphyxiation and bone marrow aseptically flushed from femurs into RPMI-1640 medium containing $4 \mathrm{mM}$ L-glutamine, 5 $\times 10^{-5} \mathrm{M}$ 2-mercaptoethanol, $1 \mathrm{mM}$ sodium pyruvate, $100 \mathrm{U} / \mathrm{ml}$ penicillin, $100 \mu \mathrm{g} / \mathrm{ml}$ streptomycin, and $0.1 \mathrm{mM}$ nonessential amino acids (complete 1640). The cell suspension was then centrifuged at 400 $g$ for $10 \mathrm{~min}$, resuspended in complete 1640 four times, and finally resuspended in $75-\mathrm{cm}^{2}$ tissue culture flasks at a density of $1 \times 10^{5}$ cells $/ \mathrm{ml}$ in complete RPMI containing $10 \% \mathrm{vol} / \mathrm{vol}$ FCS. Flasks were then incubated at $37^{\circ} \mathrm{C}$ in a $5 \% \mathrm{CO}_{2}$ humidified atmosphere. Purified murine IL-3 (a kind gift of Dr. James Ihle, St. Jude's Children Research Hospital, Memphis, TN) was added to a final concentration of 20 $\mathrm{U} / \mathrm{ml}$. Cells were passed at weekly intervals to achieve a final concentration of $1 \times 10^{5}$ cells $/ \mathrm{ml}$ at the time of feeding.

Mouse bone marrow colony-forming units were determined in a solid phase agarose system in which a feeder layer of agarose was overlaid with a cell layer in six-well plates (19). The feeder layer in each well was composed of $1.25 \mathrm{ml}$ of complete RPMI 1640 medium, 0.375 $\mathrm{ml} 2 \times$ concentrated RPMI $1640,0.5 \mathrm{ml} \mathrm{FCS}$, and $0.375 \mathrm{ml}$ of a $3.3 \%$ (wt/vol) stock agarose solution in distilled water. IL-3 was added to complete 1640 to give a final concentration of $100 \mathrm{U} / \mathrm{ml}$. The agarose was allowed to equilibrate at $37^{\circ} \mathrm{C}$ in $5 \% \mathrm{CO}_{2}$ for $1 \mathrm{~h}$ before use. The 
cell layer in each well was composed of $0.36 \mathrm{ml}$ of complete RPMI-1640, $0.18 \mathrm{ml}$ of distilled water, $0.18 \mathrm{ml}$ of FCS, and $0.18 \mathrm{ml}$ of a $0.9 \%(\mathrm{wt} / \mathrm{vol})$ stock agarose solution in distilled water and $0.1 \mathrm{ml}$ of complete RPMI 1640 containing $1 \times 10^{5}$ bone marrow cells. Colonies were examined at weekly intervals by transferring individual colonies to glass slides by means of a pasteur pipette. The cells were then mashed gently onto the slide with a coverslip before staining.

Human bone marrow cultures. Human marrow was obtained from bone marrow aspirates of patients undergoing evaluation for mastocytosis, after informed consent. Bone marrow cells were cultured with human recombinant IL-3 (rIL-3) ${ }^{1}$ (Genzyme Corp., Boston, MA) as described previously (19). Briefly, cells were diluted 1:6 in complete RPMI 1640, layered over Ficoll-Paque, and centrifuged at $800 \mathrm{~g}$ for 20 $\mathrm{min}$. The mononuclear cell layer was harvested, centrifuged at $400 \mathrm{~g}$ for $10 \mathrm{~min}$, and resuspended in complete 1640 containing $1 \%$ FCS four times, and the cells finally resuspended in complete RPMI containing $10 \%$ FCS at a concentration of $5 \times 10^{5}$ cells $/ \mathrm{ml}$. Cells were then placed over a soft agarose culture in an interphase culture system using a single layer of agarose prepared in six-well plates (19). $2 \times 10^{5}$ cells were resuspended in $400 \mu \mathrm{l}$ of complete 1640 with $10 \%$ FCS and 100 $\mathrm{U} / \mathrm{ml}$ of human recombinant IL-3 and layered over agarose in each well. The agarose layer in each well consisted of $2.5 \mathrm{ml}$ composed of $1.25 \mathrm{ml}$ of complete RPMI 1640 medium, $0.375 \mathrm{ml} 2 \times$ concentrated RPMI $1640,0.5 \mathrm{ml} \mathrm{FCS}$, and $0.375 \mathrm{ml}$ of a $3.3 \%$ (wt/vol) stock agarose solution in distilled water. rIL-3 was added to complete 1640 to give a final concentration of $100 \mathrm{U} / \mathrm{ml}$. The agarose was allowed to equilibrate at $37^{\circ} \mathrm{C}$ in $5 \% \mathrm{CO}_{2}$ for $1 \mathrm{~h}$ before use. Cells within each agarosecontaining well were fed weekly by removing $\sim 200 \mu \mathrm{l}$ of the fluid over the agarose and replacing it with complete 1640 containing $10 \%$ FCS and appropriate concentrations of human IL-3. Cells were harvested by gently pipetting culture media several times over the agarose surface. Aliquots of cells were removed at weekly intervals for cell counts, histochemistry, and histamine determinations.

Human basophil isolation. Basophils were isolated from venous blood after leukopheresis of 2 liters of blood (NIH blood bank) by single step isopycnic banding on Percoll as described (20). Briefly, $4 \mathrm{ml}$ of human polymorphonuclear leukocytes were layered onto discontinuous Percoll gradients made from solutions with densities of 1.088 , 1.079 , and $1.070 \mathrm{~g} / \mathrm{ml}$. Final adjustment of the solution was facilitated by measurement of the refractive index. The refractive index of the solutions was measured at $22^{\circ} \mathrm{C}$ with a refractometer (Bausch \& Lomb Inc., Rochester, NY). After centrifugation at $700 \mathrm{~g}$ for $25 \mathrm{~min}$ at $22^{\circ} \mathrm{C}$, the majority of the basophils were found in a band between the layered solutions having densities of 1.070 and 1.079. Basophil purity ranged from 5 to $15 \%$. Basophil yields from each leukopheresis pack were $1.5 \pm 0.4 \times 10^{6}$ cells.

Histochemical stains. Cultured cells were spun onto glass slides in a cytocentrifuge (Shandon Southern Instruments Inc., Sewickley, PA), allowed to air dry, and stained with Wright-Giemsa on an Ames Hematek automated slide stainer (Miles Laboratories Inc., Naperville, IL). Other slides were stained with acid toluidine blue (21).

Histamine assay. Aliquots of cultured cells were counted, centrifuged at $800 \mathrm{~g}$ for $10 \mathrm{~min}$, and resuspended in phosphate buffered

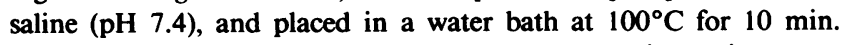
Samples were then analyzed for histamine content using an immunoassay that employs monoclonal antibodies raised against acylated histamine (22). Histamine in the sample was acylated using succinyl glycinamide $N$-hydroxysuccinimide ester which was supplied with the antibody in a kit (Amac Inc., Westbrook, ME).

Flow cytometry and cell sorting. Cell sorting was performed on an Epics 753 (Coulter Electronics Inc., Hialeah, FL) with an Argon laser (Coherent Inc., Palo Alto, CA) tuned to $488 \mathrm{~nm}$, wavelength $300 \mathrm{~mW}$. A 530/30 bandpass optical filter was used to screen the FITC emission. Multiparameter data acquisition and display system software (Coulter Electronics Inc.) and a four-decade logarithmic amplifier were used for

1. Abbreviation used in this paper: rIL-3, recombinant IL-3. statistical analysis and the data displays. Cells were kept at $4^{\circ} \mathrm{C}$ during sorting with the instrument's cooling system. To evaluate the expression of Fc $\in R I$ receptors on the cell surface of mouse and human bone marrow cells, the cells were centrifuged at $800 \mathrm{~g}$ for $10 \mathrm{~min}$ and resuspended in HBSS without calcium or magnesium or phenol red, containing 0.1 sodium azide and $0.2 \%$ bovine serum albumin. $4 \times 10^{6}$ cells in $0.5 \mathrm{ml}$ were then incubated with FITC-conjugated $\operatorname{IgE}(19,23)$ at a concentration of $25 \mu \mathrm{g} / \mathrm{ml}$ for $45 \mathrm{~min}$ at $4^{\circ} \mathrm{C}$. To ensure removal of IgE bound to low affinity IgE receptors (FceRII), the cells were washed twice. Briefly, the cells were centrifuged at $800 \mathrm{~g}$ for $10 \mathrm{~min}$, resuspended in HBSS twice, and finally resuspended in the HBSS (24). Cells were then analyzed by flow cytometry. Nonspecific fluorescence was assessed by preincubating an aliquot of the cells with $25 \mu \mathrm{g} / \mathrm{ml}$ of purified monoclonal IgE before adding the FITC-conjugated IgE.

Northern blot analysis. Total RNA was isolated by the guanidine isothiocyanate procedure (25), followed by cesium chloride centrifugation (26). $5 \mu \mathrm{g}$ of total RNA was electrophoresed in a $1 \%$ agaroseformaldehyde gel, transferred to nylon membrane, and baked for $2 \mathrm{~h}$ at $80^{\circ} \mathrm{C}(26)$. cDNA probes for the $\alpha, \beta$, and $\gamma$ IgE-receptor subunits were labeled with $\left[{ }^{32} \mathrm{P}\right] \mathrm{CTP}$ by the random prime method (27). The amount of RNA loaded on each lane was equivalent as judged by rehybridization of the same filters with a $\beta$-actin probe. Poly $(\mathrm{A}+) \mathrm{RNA}$ was prepared from basophil RNA by oligo-dT chromatography (26).

Hybridization probes. The probe for rat FceRI $\alpha$ is a 600-bp Sty I restriction fragment which encodes nucleotides 119-781 of the coding sequence (27-776) (8). The probe for rat FceRI $\beta$ is an Eco RI-Pst I restriction fragment which encodes nucleotides $1-477(10)$. The probe for rat FceRI $\gamma$ is an Eco RI-Dde I restriction fragment which encodes the entire coding region (nucleotides 1-300) (11). The cDNA for the human FceRI $\alpha$ is an Eco RI-PvU II restriction fragment which encodes nucleotides 5-652 (12).

\section{Results}

Expression of FceRI on cells in bone marrow cultures. In order to study the time of appearance of FceRI on the surface of cells during their differentiation, human and mouse bone marrow cells were placed in culture with IL-3 for $0,1,2$, and $3 \mathrm{wk}$. The number of cells staining with FITC-conjugated IgE, their size, and relative fluorescence were assessed at each time point by FACS analysis. In mouse bone marrow cultures (Fig. 1), the fluorescent intensity and the size of the cells increased remarkably from 0 to $3 \mathrm{wk}$. The fluorescence could be completely quenched by preincubation of the cells with nonfluoresceinated IgE. In human bone marrow cultures (Fig. 2), the increase in fluorescence over $3 \mathrm{wk}$ was much less dramatic than in mouse bone marrow cultures, although the cell size also increased. Nevertheless, there was a slight increase in fluorescence better seen at $3 \mathrm{wk}$ which could also be quenched with nonfluoresceinated IgE.

We next examined the appearance of mast cells and basophils in cultures of either murine or human bone marrow and correlated these findings with the percentage of FceRI-positive cells identified in Fig. 1 . As can be seen, the number of Fc $\epsilon$ RIpositive cells was $75 \%$ at $1 \mathrm{wk}$ while the number of identifiable mast cells was $25 \%$ (Fig. $3 a$ ), suggesting that the appearance of FceRI preceded the maturation of the mast cells themselves. In human bone marrow cultures, however, the number of basophils identified consistently exceeded the number of FceRIpositive cells identified by FACS analysis (Fig. $3 b$ ).

Enrichment of mast cells in mouse bone marrow cultures. The number of mast cells identified on a morphological basis in mouse bone marrow cultures increased over $3 \mathrm{wk}$ to give a culture of $\sim 90 \%$ mast cells, while the other cell types present during the early weeks of culture, such as macrophages, de- 


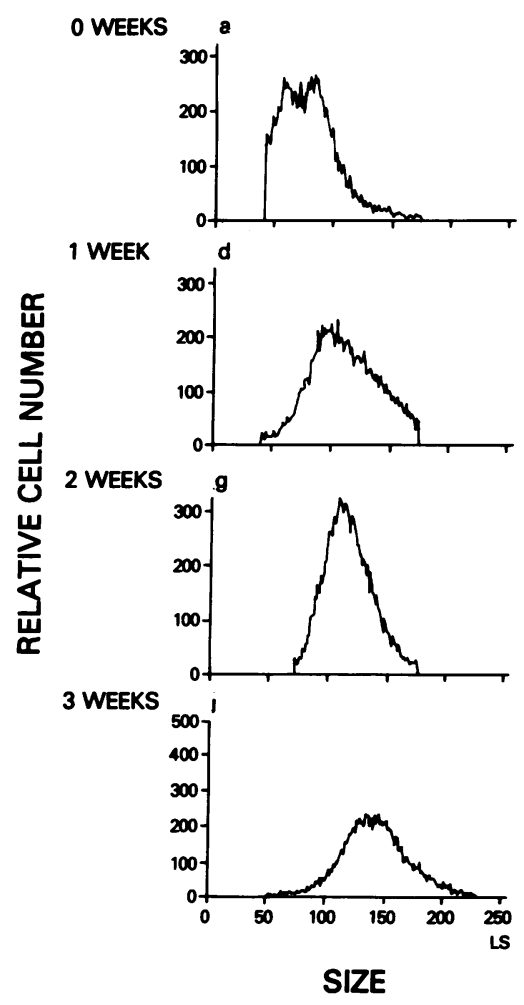

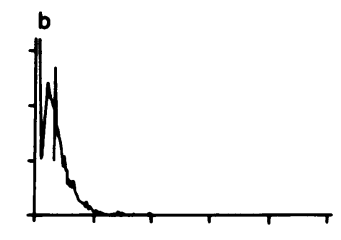
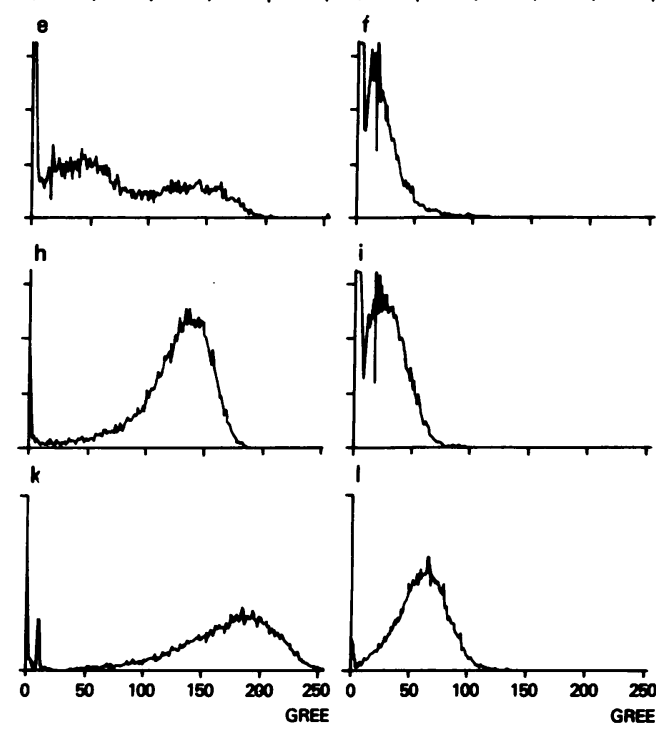

FLUORESCENT INTENSITY

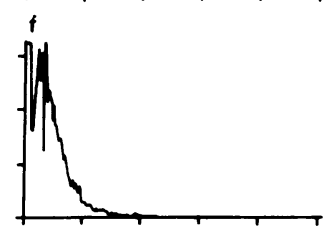

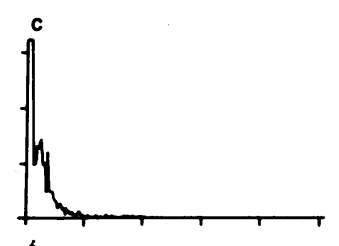

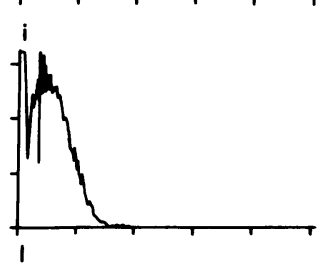

Figure 1. FACS analysis of mouse bone marrow cultures. Mouse bone marrow was cultured for $0(a, b, c), 1(d, e, f), 2$ $(g, h, i)$, and $3(j, k, l)$ wk in the presence of IL-3 and the number of cells staining with IgE-conjugated FITC at each time point examined using flow cytometry $(b, e, h, k)$. As a control, cells were also pretreated with monoclonal IgE for $1 \mathrm{~h}$ before the addition of IgEconjugated FITC $(c, f, i, l) . a, d, g$, and $j$ show the size of the respective cells at each weekly interval as determined by light scatter. LS, light scatter; GREE stands for FITC fluorescence. Experiment shown is representative of four similar experiments. creased in number (Fig. $3 a$ ). This rise in the number of mast cells was paralleled by a fivefold increase in the histamine content of these cells from 0.045 to $0.2 \mathrm{pg} /$ cell, from 1 to 3 wk. Mouse bone marrow cells placed in agarose on day 1 gave rise to $87.2 \pm 1.4,93.6 \pm 4.1$, and $94.0 \pm 6.3$ colonies per 100,000 cells at 1,2 , and 3 wk, respectively, of which $56.2 \pm 4.7$, $69.7 \pm 2.5$, and $73.1 \pm 1.6 \%$ were determined morphologically to be mast cells. Thus, it can be calculated that there are $\sim 68$ progenitors of mast cells per 100,000 bone marrow cells. Bone marrow cells grown in IL-3 and plated at 1, 2, and 3 wk gave

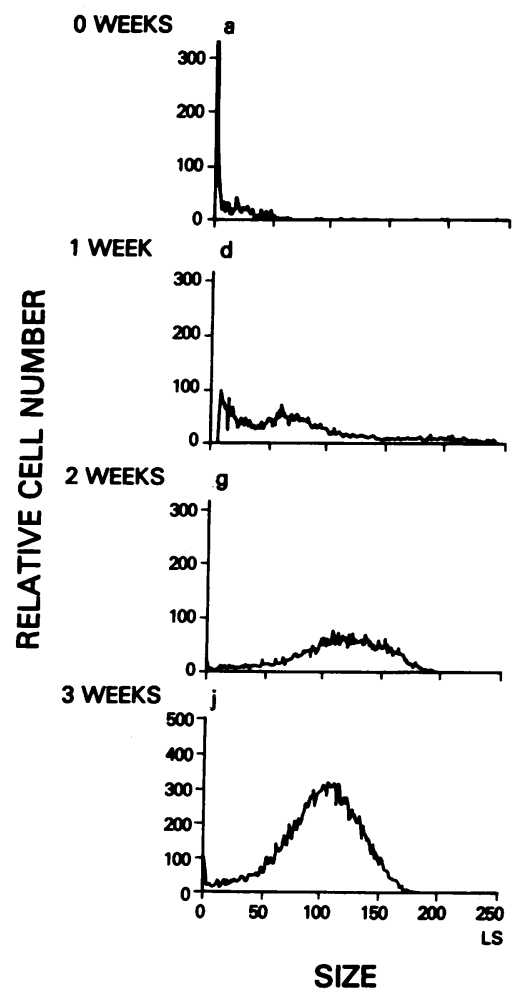

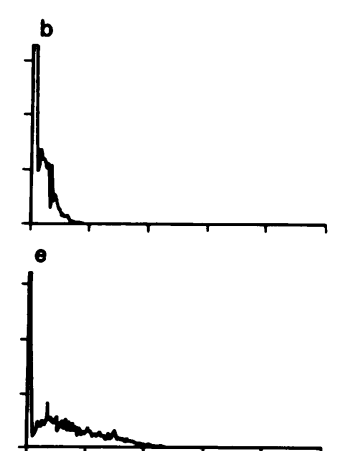
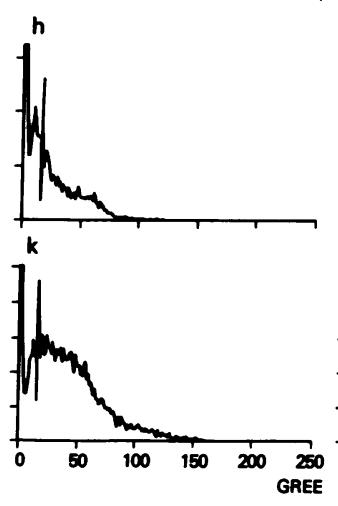

FLUORESCENT INTENSITY
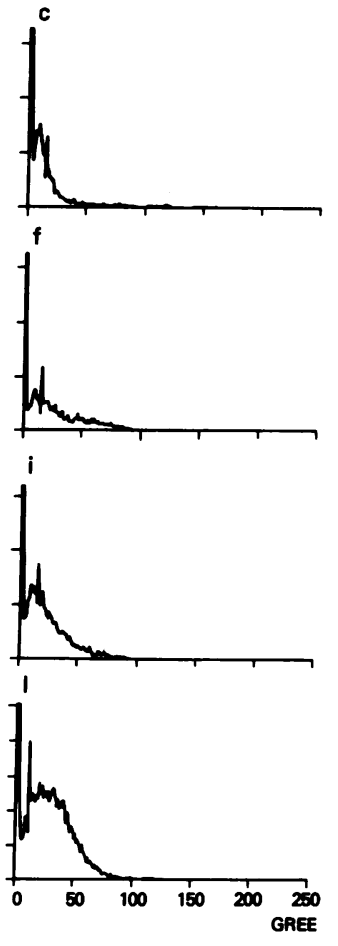

High-Affinity Immunoglobulin E Receptor Expression 

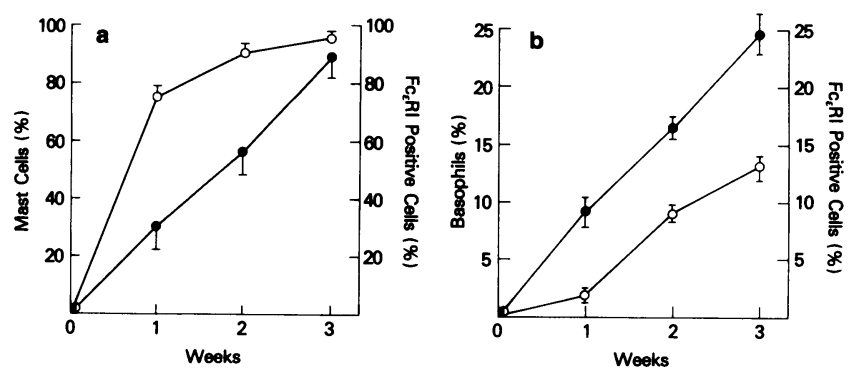

Figure 3. IL-3 induced expression of surface Fc $\in \mathrm{RI}$ and growth of (a) mast cells from mouse bone marrow or $(b)$ basophils from human bone marrow. Cultures were maintained with IL-3 as described under Methods for 0-3 wk and the percentage of cells expressing surface Fc $\in \mathrm{RI}(\mathrm{O})$ and the percentage of mast cells $(\bullet)$ or basophils $(\bullet)$ determined weekly. Results are expressed as mean \pm SEM for four experiments.

rise to small clusters of cells with less than four cells per cluster with no large colonies seen (data not shown). This suggests that at $1 \mathrm{wk}$, the majority of cells are committed progenitor cells.

When the enrichment in mouse mast cells and in FceRIpositive cells are compared (Fig. $3 a$ ), it is clear that at $1 \mathrm{wk}$, there are many more FceRI-positive cells than mast cells as defined by staining criteria. Sorting of the FceRI-positive cells in cultures of murine bone marrow using FACS confirmed that at least $50 \%$ of the cells at 1 wk of culture were not characteristic mast cells but, rather, consisted of mononuclear cells containing few if any granules.

Enrichment in basophils in human bone marrow cultures. Human bone marrow cultured for $0,1,2$, and 3 wk in the presence of rIL-3 gave rise to basophils previously identified as such by a number of criteria including electron microscopy, histamine content, and fluorescent staining with FITC-conju- gated IgE (19) and, more recently, by cell-surface markers (28) In the present study, the number of basophils identified morphologically rose to $\sim 25.0 \%$ at $3 \mathrm{wk}$ (Fig. $3 \mathrm{~b}$ ). The histamine content of these cells rose from $0.07 \pm 0.00$ to $1.2 \pm 0.04 \mathrm{pg} /$ cell, from 1 to $3 \mathrm{wk}$, in accordance with previous studies (19). When Fc $\epsilon$ RI-bearing cells were isolated by sorting at 1 wk, only small numbers of cells were obtained. These cell populations consisted of both basophils (80\%) and mononuclear cells with few if any granules (20\%).

Specific transcripts for the subunits of FcERI in mouse bone marrow cultures. Total RNA isolated from cells at different times of culture was hybridized with the cDNA probes specific for the rat $\alpha, \beta$, and $\gamma$ subunits of the FceRI. Northern blot analysis revealed mRNA species of $1.3 \mathrm{~kb}$ (Fig. $4 a$ ), $2.75 \mathrm{~kb}$ (Fig. $4 b$ ), and $0.75 \mathrm{~kb}$ (Fig. $4 c$ ) for the $\alpha, \beta$, and $\gamma$ subunits, respectively. There was a marked increase with time of the mRNA for each of the subunits (Fig. 4, top panels). To show that equivalent amounts of RNA were loaded in each lane, the same filters were rehybridized with a $\beta$-actin probe (Fig. 4 , bottom panels). The relative increase in the expression of mRNA for the three subunits is generally linear over the $3 \mathrm{wk}$ of culture when examined by densitometry (Fig. 5).

Specific transcripts for the subunit of FcERI in human bone marrow cultures. Total RNA isolated from human bone marrow cells at different time points of the culture with IL-3 was hybridized with the cDNA probes specific for the human $\alpha$ subunit of the FceRI. Northern blot analysis revealed mRNA species of $1.1 \mathrm{~kb}$ (Fig. $6 \mathrm{~b}$ ). Since cDNA clones for the human $\beta$ and $\gamma$ subunits have not yet been isolated, the total RNA from human bone marrow was hybridized with cDNA probes specific for rat $\beta$ and $\gamma$ subunits. No bands specific for $\beta$ subunit were observed, even at low stringency (data not shown). By contrast, a mRNA species specific for the $\gamma$ subunit was detected at $0.75 \mathrm{~kb}$ (Fig. $6 a$ ), which corresponds to the size of mRNA specific for rat $\gamma(11)$. The amount of RNA loaded in

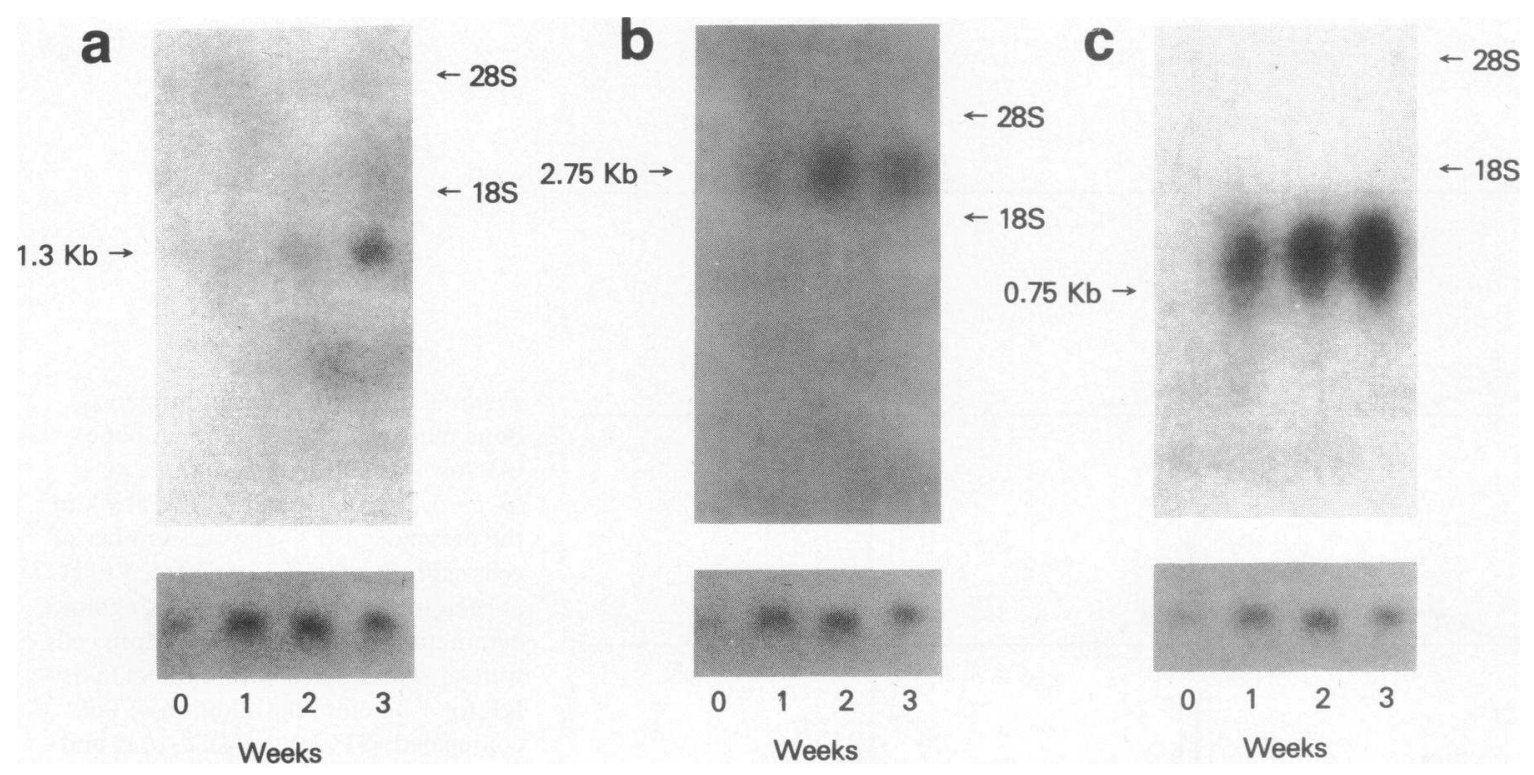

Figure 4. Northern blot analysis. Total RNA from mouse bone marrow cells cultured for $0,1,2$, and 3 wk in the presence of $20 \mathrm{U} / \mathrm{ml}$ IL-3, separated on $1 \%$ agarose gel and transferred to nylon membrane. mRNA hybridized under stringent conditions with random prime-labeled cDNA coding for the $(a, t o p) \alpha$ subunit of the rat high-affinity IgE receptor, or $(a, b o t t o m) \beta$-actin cDNA, $(b, t o p)$ the cDNA for the $\beta$ subunit of the rat high-affinity IgE receptor or $(b$, bottom) $\beta$-actin cDNA, $(c$, top) the cDNA for the $\gamma$ subunit of the rat high-affinity IgE receptor or (c, bottom) $\beta$-actin cDNA. Ribosomal markers are indicated on the right. Results shown are representative of four independent experiments. 


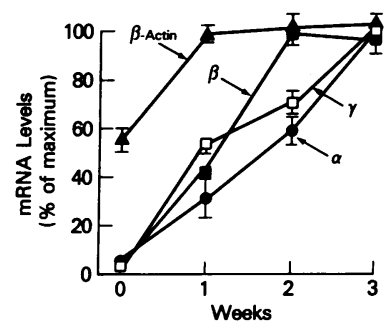

Figure 5. Densitometric scan of the autoradiograms shown in Fig. 4 and three other independent experiments. Maximum levels of absorbance were normalized to $100 \%$ and the level of expression of mRNA for the $\alpha(\bullet), \beta(\bullet)$, and $\gamma(\square)$ IgE-receptor subunits and the $\beta$-actin probe $(\Delta)$ at each weekly interval shown as a percentage of this value. Results are expressed as mean \pm SEM for four independent experiments.

each lane was again assessed by using a $\beta$-actin probe (Fig. 6, $a$ and $b$, bottom panels). There was again an increase in mRNA for the $\alpha$ and $\gamma$ subunits (Fig. 6, $a$ and $b$, top panels) shown by densitometry in Fig. 7.

The fractional enrichments in mRNA for the $\alpha$ subunit and in basophil number appear similar (compare Figs. $6 b$ and 7 with Fig. $3 b$ ). The situation seems different for the $\gamma$ subunit. This may be explained by our recent observation that $\gamma$ subunits are associated with one $\mathrm{Fc} \gamma$ receptor from macrophages. In human IL-3 cultures, macrophages represent an important population (more than in mouse IL-3 cultures) which decreases over time. Therefore, it is likely that the amount of mRNA observed in the total population of cells results from two components: the increase in Fc $\in R I$ expression in basophils, and the decrease in $\mathrm{Fc} \gamma$ receptor expression in macrophages.

Expression of FceRI in human peripheral blood basophils. To verify that mature human peripheral blood basophils also express Fc $\epsilon$ R mRNA, poly (A+) RNA isolated from human peripheral blood basophils was hybridized with the cDNA probes specific for the rat $\gamma$ subunit and the human $\alpha$ subunit of Fc $\epsilon$ RI. Northern blot analysis revealed mRNA species of 0.75 and $1.1 \mathrm{~kb}$ for the $\gamma$ and $\alpha$ subunits, respectively (Fig. $6 c$ ). This suggests that terminally differentiated cells continue to have the potential to synthesize de novo receptors.
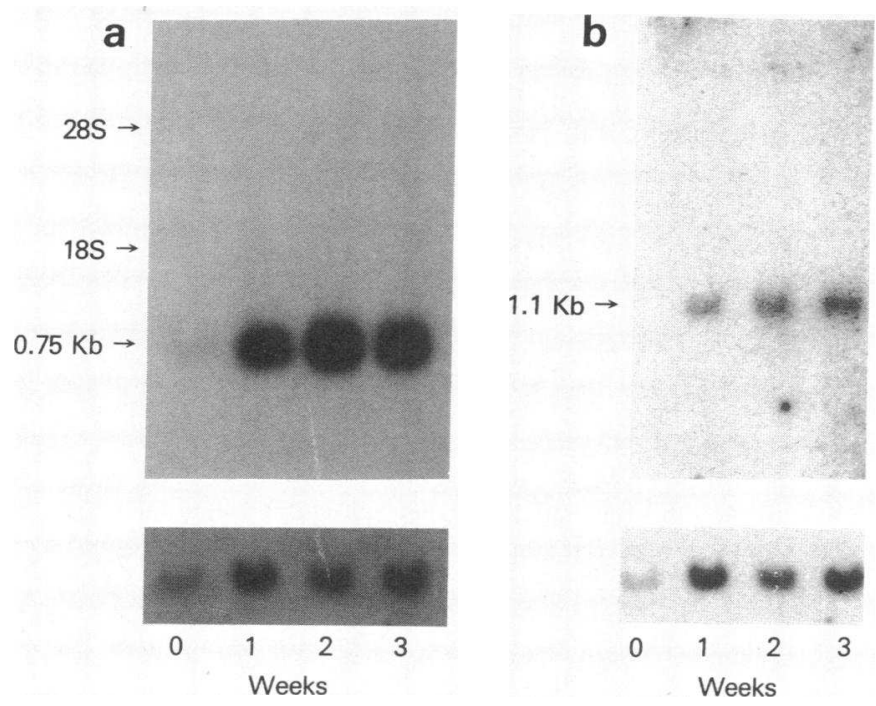

Figure 6. Northern blot analysis of $(a$ and $b$ ) total RNA obtained from human bone marrow cells cultured for $0,1,2$, and $3 \mathrm{wk}$ with rIL-3, run on $1 \%$ agarose gel, and transferred to nylon membrane. mRNA hybridized under $(a)$ low stringency with a random prime-labeled cDNA probe to the $\gamma$ subunit of the rat high-affinity IgE receptor subunit and $(b)$ high stringency with a random prime-labeled cDNA probe to the $\alpha$ subunit of the human high-affinity $\operatorname{IgE}$ receptor. (c) poly $(\mathrm{A}+)$ RNA from human basophils hybridized under high stringency with the cDNA probe to the $\alpha$ subunit of the human IgE receptor (lane 1 ), or under low stringency with the cDNA probe to the $\gamma$ subunit of the rat IgE receptor (lane 2). Results shown are representative of three independent experiments. 


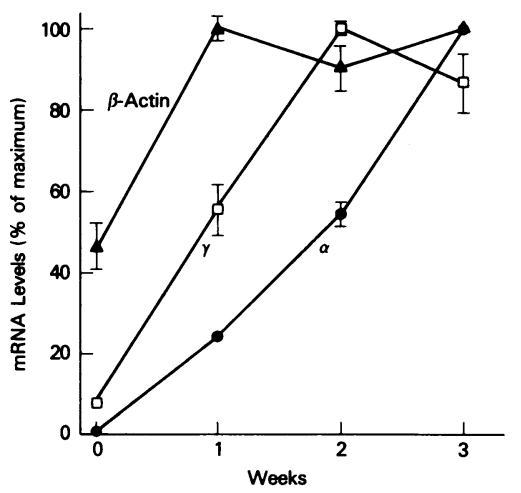

Figure 7. Densitometric scan of the autoradiograms shown in Fig. 6, $a$ and $b$, and two other independent experiments. Maximum levels of absorbance were normalized to $100 \%$ and the level of expression of mRNA for the $\alpha(\bullet)$ and $\gamma(\square) \operatorname{IgE}$-receptor subunits and the $\beta$-actin probe at each weekly interval shown as a percentage of this value. Results are expressed as mean \pm SEM for three individual experiments.

population of cells. The situation might, in fact, be more analogous to mouse differentiation than initially apparent. $20 \%$ of receptor-positive cells, when sorted, could not be recognized as basophils (or mast cells), and it is likely that these cells represent committed cells.

This study demonstrates that transcripts for FceRI are apparent early in the process of differentiation, even before other classical markers of mast cell maturity. Therefore, the transcripts for the receptor, particularly for the $\alpha$ subunit, could be used as a marker to detect these differentiating cells. Because of the rapid development of the polymerase chain-reaction techniques, it is now conceivable to look at isolated cells to assess their content in specific transcripts. It may be possible to detect individual bone marrow cells that are committed to becoming mast cells or basophils and to study the in vivo acquisition of phenotypic features for a single cell progenitor.

The presence of mRNA for the $\alpha$ and $\gamma$ subunits of Fc $\epsilon$ RI in peripheral blood human basophils indicates the capacity of these cells to synthesize de novo receptor. It would be interesting to test whether the triggered cells conserve that capacity. Regardless of the answer to that question, that finding allows one to envisage receptor synthesis as a potential target for future therapy.

Much remains to be determined in respect to the regulation of Fc $\epsilon$ RI expression during cell differentiation. For example, nothing is known about the transcriptional control of the genes coding for the receptor. When their promoters are isolated, it will be important to determine whether they are directly under the control of IL-3. Mast cells have been shown to secrete IL-3 and IL-4, among other factors (29-32), in response to antigen triggering through Fc $\epsilon$ RI. Therefore, antigen triggering should stimulate, via IL-3, cell differentiation and receptor production. The latter could then be responsible for a positive feed back: more triggering and more receptor expression. Then, finding a way to break the loop could have therapeutic implications.

The consequences of IgE-mediated receptor activation in mast cell and basophil progenitors also requires exploration. It is interesting to speculate that the recent description of non- $T$ and non-B cells that secrete IL-3 and IL-4 in response to IgEmediated activation $(33,34)$ is due to the presence of a functional FceRI receptor on pre-mast cells and pre-basophils. If true, that would mean that both mast cells and basophils dur- ing development and before the expression of granule-mediated responses, are capable of significant biological function.

\section{Acknowledgments}

The authors would like to thank Brenda Rae Marshall for manuscript preparation and Susan Barbieri for assistance with FACS analysis and cell sorting.

\section{References}

1. Metzger, H., G. Alcaraz, R. Hohman, J.-P. Kinet, V. Pribula, and R. Quarto. 1986. The receptor with high affinity for immunoglobulin IgE. Annu. Rev. Immunol. 4:419-470.

2. Conrad, D. H., I. Berzci, and A. Froese. 1976. Characterization of the target cell receptor for IgE. I. Solubilization of IgE-receptor complexes from rat mast cells and rat basophilic leukemia cells. Immunochemistry. 13:329-332.

3. Kulcyzcki, A., Jr., T. A. McNearney, and C. W. Parker. 1976. The rat basophilic leukemia cell receptor for IgE. I. Characterization as a glycoprotein. J. Immunol. 117:661-665.

4. Holowka, D., H. Hartmann, J. Kannelopoulos, and H. Metzger. 1980. Association of the receptor for IgE with an endogenous polypeptide on rat basophilic leukemia cells. J. Recept. Res. 1:41-68.

5. Holowka, D., and H. Metzger. 1982. Further characterization of the $\beta$ component of the receptor for IgE. Mol. Immunol. 19:219-227.

6. Perez-Montfort, R., J.-P. Kinet, and H. Metzger. 1983. A previously unrecognized subunit of the receptor for immunoglobulin $\mathrm{E}$. Biochemistry. 22:5722-5728.

7. Alcaraz, G., J.-P. Kinet, T. Y. Liu, and H. Metzger. 1987. Further characterization of the subunits of the receptor with high affinity for immunoglobulin E. Biochemistry. 26:2569-2574.

8. Kinet, J.-P., H. Metzger, J. Hakim, and J. Kochan. 1987. A cDNA presumptively coding for the $\alpha$ subunit of the receptor with high affinity for immunoglobulin E. Biochemistry. 26:4605-4610.

9. Shimizu, A., I. Tepler, P. N. Benfey, E. H. Berenstein, R. P. Siraganian, and P. Leder. 1988. Human and rat mast cell high-affinity immunoglobulin E receptors: characterization of putative $\alpha$-chain gene products. Proc. Natl. Acad. Sci. USA. 85:1907-1911.

10. Kinet, J.-P., U. Blank, C. Ra, K. White, H. Metzger, and J. Kochan. 1988. Isolation and characterization of cDNAs coding for the $\beta$ subunit of the high affinity receptor for immunoglobulin E. Proc. Natl. Acad. Sci. USA. 85:6483-6487.

11. Blank, U., C. Ra, L. Miller, K. White, H. Metzger, and J.-P. Kinet. 1989. Complete structure and expression in transfected cells of high affinity IgE receptor. Nature (Lond.). 337:187-189.

12. Kochan, J., L. F. Pettine, J. Hakimi, K. Kishi, and J.-P. Kinet. 1988. Isolation of the gene coding for the $\alpha$ subunit of the high affinity IgE receptor. Nucleic Acids Res. 16:3584.

13. Miller, L., U. Blank, H. Metzger, and J.-P. Kinet. 1989. Expression of high affinity binding of human immunoglobulin $E$ by transfected cells. Science (Wash. DC). 244:334-337.

14. Metcalf, D. 1985. The granulocyte-macrophage colony stimulating factors. Science (Wash. DC). 229:16-21.

15. Ihle, J. N., J. Keller, S. Orozlan, L. Henderson, T. D. Copeland, F. Fitch, M. B. Prytowsky, E. Goldwasser, J. W. Schrader, E. Palazynski, M. Dy, and B. Lebel. 1983. Biological properties of interleukin-3. I. Demonstration of WEHI-3 growth factor activity, mast cell growth factor activity, $P$ cell-stimulating activity, colony-stimulating activity and histamine-producing cell-stimulatory activity. J. Immunol. 131:282-289.

16. Prystowky, M. B., G. Otten, M. F. Naujokas, J. Vardiman, J. N. Ihle, E. Goldwasser, and F. W. Fitch. 1984. Multiple hemopoietic lineages are found after stimulation of mouse bone marrow precursor cells with interleukin-3. Am. J. Pathol. 117:171-176.

17. Ihle, J. N., and Y. Weinstein. 1986. Immunological regulation of hematopoietic/lymphoid stem cell differentiation by interleukin-3. Adv. Immunol. 39:1-50. 
18. Razin, E., J. N. Ihle, D. Seldin, J.-M. Mencia-Huerta, H. R. Katz, P. A. Leblanc, A. Hein, J. P. Caulfield, K. F. Austen, and R. L. Stevens. 1984. Interleukin-3: a differentiation and growth factor for the mouse mast cell that contains the chondroitin sulfate $\mathrm{E}$ proteoglycan. J. Immunol. 132:1479-1486.

19. Kirshenbaum, A., J. Goff, A.-M. Irani, L. Schwartz, and D. D. Metcalfe. 1989. Interleukin-3-dependent growth of basophil-mast-like cells from human bone marrow. J. Immunol. 142:2424-2429.

20. Leonard, E. J., R. L. Roberts, and A. Skeel. 1984. Purification of human blood basophils by single isopycnic banding on Percoll. $J$. Leukocyte Biol. 35:169-177.

21. Saavedra-Delgado, A. M. P., S. Turpin, and D. D. Metcalfe. 1984. Typical and atypical mast cells of the rat gastrointestinal system: distribution and correlation with tissue histamine. Agents and Actions. 14:1-5.

22. Morel, A. M., and M. A. Delaage. 1988. Immunoanalysis of histamine through a novel chemical derivatization. J. Allergy Clin. Immunol. 82:646-654.

23. Forni, L. 1979. Reagents for immunofluorescence and their use for studying lymphoid cell products. In Immunological Methods. I. Leftkovits and B. Pernis, editors. Academic Press, New York. 151.

24. Spiegelberg, H. L. 1984. Structure and function of Fc receptors for IgE on lymphocytes, monocytes and macrophages. Adv. Immunol. 35:61-88.

25. Chirgwin, J. M., A. E. Przbyla, R. J. MacDonald, and W. J. Rutter. 1979. Isolation of biologically active ribonucleic acid from sources enriched in ribonuclease. Biochemistry. 18:5294-5299.

26. Maniatis, T., E. F. Fritsch, and J. Sambrook. 1982. Molecular Cloning: A Laboratory Manual. Cold Spring Harbor Laboratory, Cold Spring Harbor, NY. 545 pp.
27. Feinberg, A. P., and B. Vogelstein. 1982. A technique for radiolabeling DNA restriction endonuclease fragments to high specific activity. Anal. Biochem. 132:6-13.

28. Valent, P., G. Schmidt, J. Besemer, P. Mayer, G. Zenke, E. Liehl, W. Hinterberger, K. Lechner, D. Maurer, and P. Bettelheim 1989. Interleukin-3 is a differentiation factor for human basophils. Blood. 73:1763-1769.

29. Plaut, M., J. H. Pierce, C. J. Watson, J. Hanley-Hyde, R. P. Nordan, and W. E. Paul. 1989. Mast cell lines produce lymphokines in response to cross-linkage of FceRI or to calcium ionophores. Nature (Lond.). 339:64-67.

30. Wodnar-Filipowicz, A., C. H. Heusser, and C. Moroni. 1989. Production of the haemopoietic growth factor GM-CSF and interleukin-3 by mast cells in response to IgE receptor-mediated activation. Nature (Lond.). 339:150-152.

31. Takagi, M., T. Nakahata, K. Kenichi, T. Kobayashi, K. Tsuji, S. Kojima, T. Hirano, A. Miyajima, K.-I. Arai, and T. Akabane. 1989. Stimulation of connective tissue-type mast cell proliferation by crosslinking of cell-bound IgE. J. Exp. Med. 170:233-245.

32. Burd, P. R., H. W. Rogers, J. R. Gordon, C. A. Martin, S. Jayaraman, S. D. Wilson, A. M. Dvorak, S. J. Galli, and M. E. Dorf. 1989. Interleukin-3-dependent and -independent mast cells stimulated with IgE express multiple cytokines. J. Exp. Med. 170:245-259.

33. Conrad, D., S. Z. Ben-Sasson, G. LeGros, M. Plaut, F. D. Finkelman, and W. E. Paul. 1989. Splenic non-T, non-B cells produce IL-4 and IL-3 in response to aggregated immunoglobulins. Abstracts of the 7th International Congress of Immunology, Berlin (West). 457.

34. LeGros, G., S. Z. Ben-Sasson, D. Conrad, F. D. Finkelman, and W. E. Paul. 1989. Immunization and IL-3 treatment enhance IL-4 production by splenic non-B, non- T cells. Abstracts of the 7th International Congress of Immunology, Berlin (West). 466. 